\title{
Study on Risk Management of Green Asset Securitization in Longyuan Power
}

\author{
HongYun Jiang ${ }^{1}$, YunFei Shi ${ }^{1}$ \\ ${ }^{1}$ Business School of Guilin University of Technology, Guilin, 541004, China
}

\begin{abstract}
In recent years, with the continuous attention and construction of the combination of environmental protection and economic benefits at the national level, green economy has become the focus of attention in the current industry. The green industry dominated by pollution prevention, resource recycling, new energy technology and other industries can make up for the lack of financing ability of enterprises mainly in green industry in traditional banks and capital markets. As an important part of green economy, green asset securitization is developing into a bridge. It is connecting social capital and green industrial enterprises. Green asset securitization will bring more powerful economic support to the development of enterprises. This paper takes China's green industrial enterprise Longyuan Power Group Co., Ltd. as an example to analyze the risks of green asset securitization to the enterprise and the risk management measures. Focusing on the practice, the paper studies the development status and future trend of green asset securitization on enterprises.
\end{abstract}

\section{RELATED CONCEPTS}

\subsection{Asset Securitization}

Asset securitization refers to the special purpose company set up by securities companies, fund management companies and other related parties. The company adopts a variety of credit enhancement methods, mainly issuing securities products. It is a new financing tool to meet the demand of the future repayment of principal and interest of securitized products.

\subsection{Securitization of Green Assets}

On August 15, 2018, The "Shanghai stock exchange asset backed securitization business question and answer" published by Shanghai Stock Exchange on the asset securitization business declaration system defines green asset securitization products. The basic assets in the green industry accounted for more than $70 \%$ of all the pooled assets. The amount of funds raised for investment in green projects shall be more than $70 \%$ of the total amount. The primary business of the original stakeholder belongs to the field of green industry, and the revenue of green business shall exceed $50 \%$, or the revenue and profit of green business shall exceed $30 \%$, and $70 \%$ of the total amount is from the development of the enterprise's green business. If one of the above three conditions is satisfied, it can be identified as green asset securitization. Green asset securitization is an innovative type of green bonds. Although it is not clearly defined in the policy, it is essentially asset securitization. The main difference between it and traditional asset securitization is that it has the green attribute. Green asset securitization is the organic combination of green finance and asset securitization. The future cash flow of swimming pool assets comes from green development projects or innovative financing tools invested in the field of green development.

\section{COMPANY INTRODUCTION}

\subsection{Basic Information of Longyuan Power}

Longyuan Power Holdings Limited is a Hong Kong investment holding company and it mainly engaged in power plant operation and generation business. The company operates through two divisions. One is the wind power sector, which builds, manages and operates wind farms that produce and sell electricity to grid companies. The second is the thermal power sector, which builds, manages and operates coal-fired power plants and produces and sells electricity to grid companies. The department also trades in coal. The company's other businesses include manufacturing and selling power generation equipment, providing consulting services, and providing maintenance and training services to wind power companies and other renewable energy power generation businesses.

\subsection{The Development of Green Asset Securitization of Longyuan Power Company}

According to the announcement of Longyuan Power 
(00916), the funds raised by issuing green asset-backed notes since 2017 will be mainly used for green project construction, replacing the interest bearing debt

the interest bearing debt project. The release history is shov
Table 1. Issuing History of Longyuan Power's Green Asset Securitization

\begin{tabular}{|c|c|c|c|c|}
\hline Name of The Bond & $\begin{array}{c}\text { Date of } \\
\text { Issue }\end{array}$ & $\begin{array}{c}\text { gross } \\
\text { circulation }\end{array}$ & $\begin{array}{c}\text { credit } \\
\text { rating }\end{array}$ & $\begin{array}{c}\text { Lead the lead } \\
\text { underwriter and debt } \\
\text { agent }\end{array}$ \\
\hline $\begin{array}{c}\text { yuan Green Debt } \\
\text { 18 Longyuan } \\
\text { Green } \\
\text { Debt }\end{array}$ & $\begin{array}{c}\text { April 23, } \\
2018\end{array}$ & 3billion & AAA & $\begin{array}{c}\text { Huatai United Securities } \\
\text { Co. Ltd }\end{array}$ \\
\hline $\begin{array}{c}\text { G Long } \\
\text { yuan Y3(For } \\
\text { Professional } \\
\text { Investors) }\end{array}$ & $\begin{array}{c}\text { October } \\
27,2020\end{array}$ & 1billion & - & Huatai United Securities \\
\hline $\begin{array}{c}\text { G Longyuan Y4 } \\
\text { (For Professional } \\
\text { Investors) }\end{array}$ & $\begin{array}{c}\text { October 27, } \\
2020\end{array}$ & 1billion & - & $\begin{array}{c}\text { Huatai United Securities } \\
\text { Co. Ltd }\end{array}$ \\
\hline
\end{tabular}

Data source: Longyuan Power Company announcement collated

\subsection{Longyuan Power's Green Asset Securitization Model}

The green asset securitization model carried out by Longyuan Power relies on the expected cash flow of the enterprise's underlying assets as the repayment support. Credit enhancement through a structured design and the issuance of asset-backed securities on this basis. Its main core lies in relying on asset financing rather than using the main body to finance. The largest and most stable basic assets of Longyuan Power are the relatively stable power generation income from electricity service agencies in the future and the renewable energy power generation policy subsidies from the government. The earning right through renewable energy generation is the high-quality target of Longyuan Power's green asset securitization, which revitalizes the enterprise's illiquid basic assets and realizes the early recovery of part of the capital. generated by green project construction, and supplementing the supporting working capital of green project. The release history is shown in Table 1: 


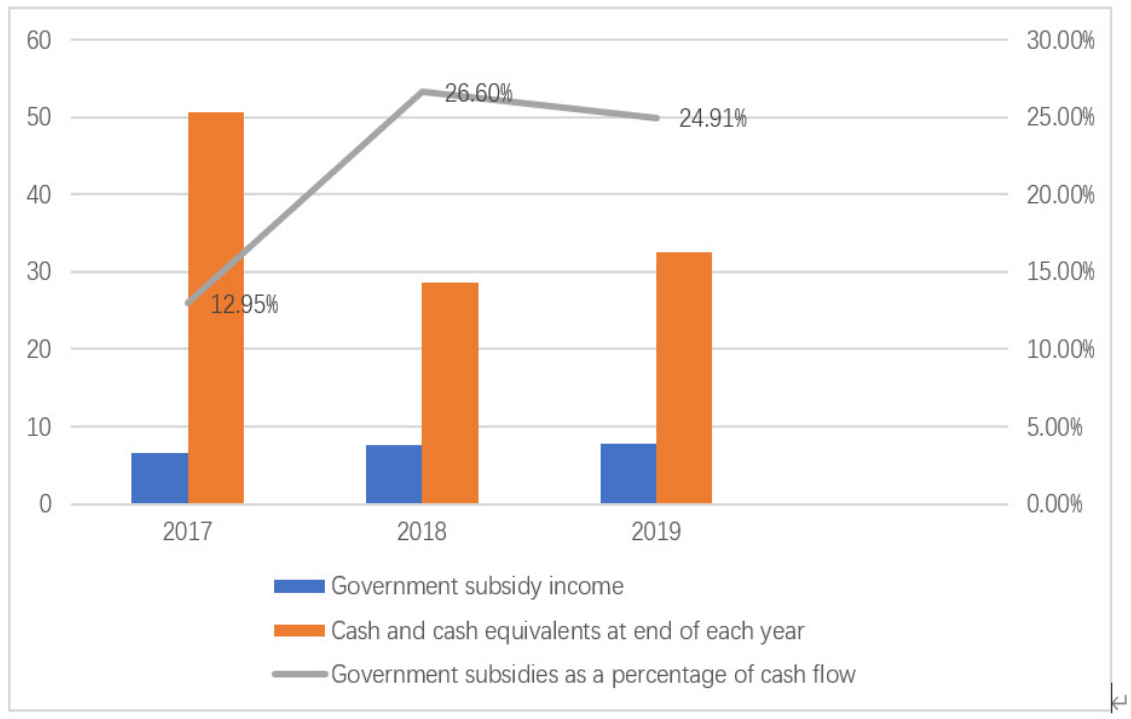

Figure 1: Government Subsidy Income and Cash Flows Data source: Compiled according to company annual reports from 2017 to 2019

\subsection{The Risk of Electricity Price Fluctuation}

The underlying assets should fully consider the risks of national policies and electricity price fluctuations. The basic asset of this special plan is the wind farm's revenue from charges, which comes from the electricity fee income of enterprises and residents. The future income of the special plan mainly depends on the cash flow of a single target. Therefore, Longyuan Power may have some pressure on debt repayment. In addition, In addition, Longyuan Power is in the wind power industry. The service group of the wind farm is mainly the public.
Its electricity price is strongly restricted by the government, and its electricity price is mainly implemented in accordance with the electricity price approved by the National Development and Reform Commission. According to figure 2, the electricity prices will decrease year by year from 2015 to 2020, which will also directly affect the profitability of the on-grid electricity charges of the underlying assets of wind farms. The on-grid tariff standard will be adjusted according to the change of national policy and price adjustment, which may affect the business situation of enterprises and the future cash flow of green asset securitization.

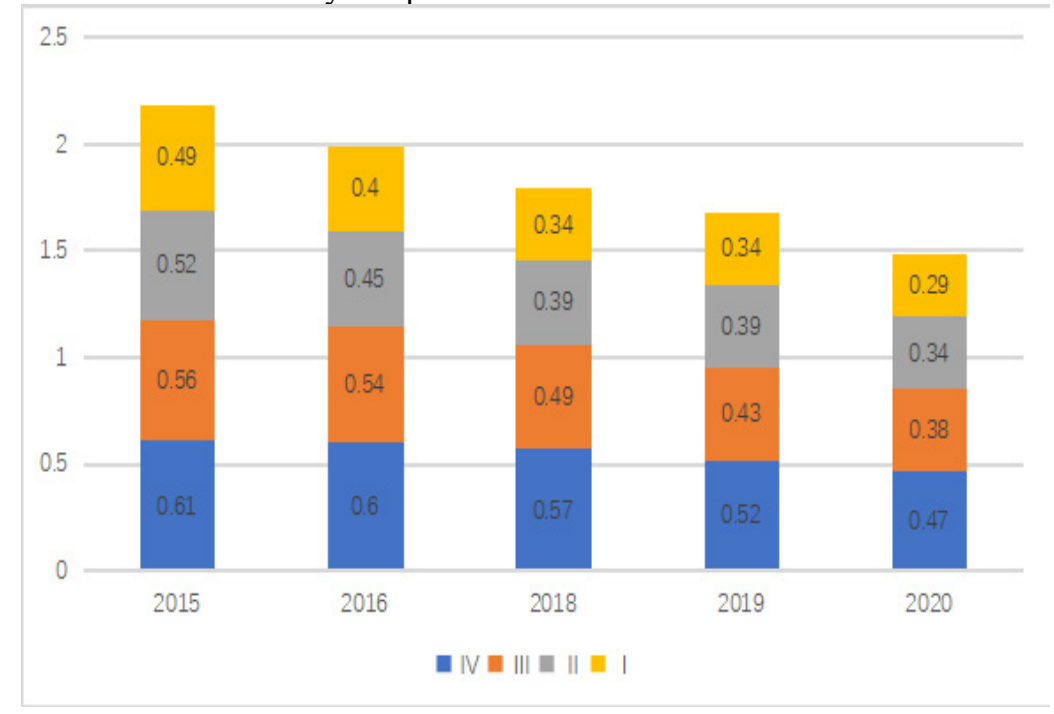

Figure. 2 Risk Feed-in Tariff Adjustment Scheme from 2015 to 2020 (yuan /kWh)

Data source: open data collation

\subsection{The Risk of Collection of Accounts Receivable}

On the one hand, accounts receivable corresponding to initial assets are all renewable energy subsidies, and accounts receivable account for a high proportion of current assets from 2017 to 2019, and more than 50\% in 2018 and 2019, accounting for half of current assets. As shown in table 2, so far, the resources and development conditions better in some areas, onshore wind has not need subsidies. By 2021, China's onshore wind power will be fully connected to the grid at affordable prices, which will significantly enhance its market 
competitiveness. Longyuan Power accounts receivable have not been fully recovered, if the national policy changes, the company will face the risk of a large number of bad debts. On the other hand, according to the "Renewable Energy Electricity Price Additional Subsidy Funds Management Measures", the Ministry of Finance will allocate the subsidy funds of renewable energy electricity price additional funds to the provincial financial departments according to the additional income of renewable energy electricity price, the fund application of provincial power grid companies and local independent power grid companies, etc. The financial departments at the provincial level shall allocate funds in accordance with the relevant provisions of the Treasury

Table 2: Value of Current Assets and Accounts Receivable of Longyuan Power from 2017 to 2019

\begin{tabular}{|c|c|c|c|c|c|c|}
\hline & \multicolumn{2}{|c|}{2019} & \multicolumn{2}{c|}{2018} & \multicolumn{2}{c|}{2017} \\
\hline & $\begin{array}{c}\text { Numerical } \\
\text { Value (ten } \\
\text { thousand } \\
\text { yuan) }\end{array}$ & Percentage & $\begin{array}{c}\text { Numerical } \\
\text { Value (ten } \\
\text { thousand } \\
\text { yuan) }\end{array}$ & $\begin{array}{c}\text { Pumerical } \\
\text { Palue (ten } \\
\text { thousand } \\
\text { yuan) }\end{array}$ & Percentage \\
\hline $\begin{array}{c}\text { Liquid } \\
\text { assets }\end{array}$ & 9188.45 & $100 \%$ & 7714.46 & $100 \%$ & 7193.91 & $100 \%$ \\
\hline Receivables & 5172.56 & $56.29 \%$ & 4462.77 & $57.85 \%$ & $3316.65 \%$ & $46.1 \%$ \\
\hline
\end{tabular}

Data source: open data collation

\subsection{Risk of Insufficient Disclosure of Information on The Use of Funds}

Although the CSRC's disclosure requirements on green asset securities did not involve the purpose of funds raised, and Longyuan Power did not disclose the specific use of funds when issuing green asset securities in Shanghai Stock Exchange. The reason is that green asset securitization in China has been developing for a short time and the relevant laws and regulations are not perfect, which may lead to the risk of fund misappropriation. However, it is necessary to improve the disclosure mechanism of the specific use of enterprise special funds so as to promote the long-term and effective development of the green securitization market. Huaneng co., LTD. is responsible for your sincere trust Longyuan green asset securitization financing operation and maintenance. But, if in the daily operation, the project company has some problems such as poor management or improper operation, which leads to a serious shortage of funds. In order to ensure the operation of the company, the project company will probably use the funds of the special plan to make up for the problems of the enterprise. If the project company fails to improve its operating situation after the embezzlement, or if the cash flow generated is less than the embezzled funds, it will be a serious blow to the normal operation of the project. Thereby, the credit enhancement measures at the beginning of the plan design will increase the risk of Longyuan power itself. management system; Provincial power grid enterprises and local independent power grid enterprises shall settle the electricity charges with the renewable energy power generation enterprises on a monthly basis according to the on-grid electricity price of renewable energy and the on-grid electricity amount actually purchased by the renewable energy power generation enterprises. The settlement process of additional subsidy funds for electricity price of renewable energy is complicated and involves multiple subjects in the transaction process, which makes the collection cycle of enterprise accounts receivable longer. If the funds are not in place before the interest payment period, the risk of failing to pay the debt interest normally will be generated.

\section{Longyuan Power Promotes The Risk Control of Green Asset Securitization}

\subsection{Improve The Stability of Corporate Cash Flow, Reduce the Reliance on Government Subsidies}

In order to deal with the potential risks encountered by wind power generation projects, enterprises need to strengthen the upgrading of wind power generation equipment, pay attention to the improvement of the technical level, improve the capacity of power generation equipment, and increase the income of power generation. Establish a big data analysis center, monitor and record daily production capacity by artificial intelligence and data analysis system, establish an early warning value mechanism, and improve the ability to estimate future production capacity. Secondly, negotiate with the power service provider in advance to confirm the basic electricity demand and the minimum electricity price, so as to ensure that the enterprise can obtain part of the basic assets before obtaining the government subsidies, collect the basic assets in time, ensure the stability of the enterprise's cash flow, and use it as a partial source of repayment in the future, reduce the dependence on government subsidies, and give investors confidence to promote green asset securitization financing.

\subsection{To Avoid The Risk of Electricity Price Fluctuations}

Revenue from the charges generated by wind farms is the 
basic asset of this special plan. The charges are mainly from the electricity charges paid by enterprises and consumers, and the electricity price is subject to policy constraints. The enterprise should avoid the risk of electricity price, actively negotiate with the power supply service agencies, confirm the basic electricity demand and the lowest electricity price in advance, obtain part of the funds from customers in advance, and ensure that the enterprise can obtain part of the basic assets. Enterprises can also summarize and stratify the local government subsidized electricity price and carry out stratified management. By means of hierarchical management, the differences between different layers can be reduced, and appropriate cross-regional distribution can be carried out according to product differences and consumption differences, so that enterprises can obtain more income from high-priced subsidy areas. At the same time, the government subsidy process should be simplified, improve the speed of allocation, and promote the better and faster development of Longyuan power.

\subsection{Strengthen The Management of Accounts Receivable and Reduce The Risk of Payment Collection}

The enterprise shall establish a regular financial reconciliation mechanism with the government appropriation unit, appoint special personnel to closely communicate with the government departments, and ensure the smooth exchange of information between the two parties. The enterprise also needs to strengthen the management of receivables corresponding to the initial assets of renewable energy subsidies, and classify all receivables of the project. Monitor the arrival time of subsidy payment, analyze and record it. Form a reasonable prediction of the payment collection time when the next subsidy payment is generated. At the same time, enterprises should hire professional legal advisory institutions to provide basic legal protection for enterprises. Cooperation with other financial institutions could also be strengthened in order to obtain other sources of financial support in the event that funds do not arrive.

\subsection{Improve The Intensity of Information Disclosure and Restrict The Use of Funds}

Sustainable and transparent information disclosure is the key to ensure the healthy development of green asset securitization. For green financial products, continuous public disclosure of project environment is necessary. For green asset-backed securities, some of the supervisors of China Securities Regulatory Commission (CSRC) that have issued green asset securitization have also disclosed the raising funds and information disclosure requirements in their specifications, but there is no clear disclosure standard. Longyuan should adhere to the disclosure of money into the whole cycle, such as project basic information, environmental benefits, and to raise funds to track the disclosure, with the help of third party agencies to do detailed and continuous information disclosure, make sure to raise money for project green assets, increasing the use of funds transparency and to facilitate public understanding of and supervision.

\section{Conclusion}

As an emerging financing mode, green asset securitization has been proven to be superior and feasible in Longyuan Power Group, which has alleviated a series of financing problems such as financing difficulty and high financing cost, and provided a convenient way for Longyuan Power to finance in the future. At the same time, it can also promote the internal optimization of enterprises, accelerate the adjustment and upgrading of enterprises, and close cooperation between enterprises and government regulatory departments, banks, exchanges and other financial institutions. Although there are certain risks in the process of issuing, if the enterprise does a good job in risk control and reasonably avoids the issuing risks, the benefits to the enterprise will still outweigh the disadvantages in the future. With the comprehensive development of asset securitization in the Chinese market, the relevant supporting facilities and legal provisions will be improved day by day. The overall environment for the development of green asset securitization will be better and better. Enterprises need to make a comprehensive layout of green asset securitization in the future, predict future risks and establish coping mechanisms, further promote the positive effects of green financial system on enterprises, so as to establish strategic advantages of enterprises in the industry.

\section{References}

1. Yun Zhiting, Wang Chenyu, Xie Fengze. Product Categories and Application Scenarios of Green Asset Securitization in China $[\mathrm{J}]$. Finance Longitudinal Horizons, 2020(06):87-92.

2. Wang Jieyu. Characteristics, Models and Suggestions of Green Asset Securitization [J]. Financial Review, 2019(11): 83-88.

3. Cao Ping. Innovative Development of Green Asset Securitization [N]. Securities Times, 2016-03-22 (A03).

4. Zhang Hongwei. The Application of Green Assets Securitization for Renewable Energy Subsidies in Power Generation Enterprises [J].China Electric Power Enterprise Management,2019(04):84-85.

5. Yu Lofeng. Research on Green Asset Securitization in China [D]. Wuhan: Huazhong University of Science and Technology, 2017.

6. Gao Xuepeng. Research on The Performance and Risk of Green Asset Securitization in Goldwind PPP Project [D].Hebei: Hebei University of Economics and Business, 2020.

7. Jingjing Sun,Li Shi. The Development Strategy of Green Assets Securitization under The Rural Revitalization Strategy[A]. Shandong University 
(Weihai). Proceedings of 3rd International Conference on Politics, Economics and Law (ICPEL 2018) (Advances in Social Science, Education and
Humanities Research, VOL.246) [C].Shandong University(Weihai):Jinan Guanping Conference Service Co., Ltd.,2018:4. 